\title{
Characterisation of Tailings from Itakpe Iron Ore Mine, Itakpe, Nigeria
}

$$
\text { Adebimpe R.A }{ }^{1, a} \text { and Fatoye A.O }{ }^{2}
$$

\author{
${ }^{1}$ Department of Mineral and Petroleum Engineering, The Federal Polytechnic, Ado-Ekiti, \\ Ekiti State, Nigeria
}

${ }^{2}$ Department of Science Technology, The Federal Polytechnic, Ado-Ekiti, Ekiti State, Nigeria

arasheed4u1@yahoo.com

\section{Keywords: Chemical Composition, Iron Ore, Minerals, Tailings}

\begin{abstract}
Knowledge of tailings characteristics is required for utilisation and management purposes in the mining and construction industry. Tailings from the mine waste dumps at Itakpe iron ore mine were collected and analysed in the laboratory to determine their chemical and physical characteristics and these include; permeability, porosity, specific gravity, particle size distribution, chemical composition and bioavailability factor of element. Geochemical speciation with quantitative X-ray powder diffraction was used to evaluate the chemical and mineral composition of Itakpe iron ore tailings. The aim is to offer base line data necessary to assess metal mobility and bioavailability. The distribution of heavy metals such as $\mathrm{Cu}, \mathrm{Ni}, \mathrm{Cd}, \mathrm{Cr}, \mathrm{Zn}$ and Fe was determined using multi- step sequential extraction. The results obtained indicate that the permeability is $6.24 \times 10^{-3} \mathrm{~cm} / \mathrm{sec}$; porosity is $35 \%$; and specific gravity is 3.58 . The tailings are well graded and is sand gravel. Nickel and Zinc was found to be considerably high in exchangeable and bound to carbonates fraction which are mobile region and is bound to $\mathrm{Fe}-\mathrm{Mn}$ oxides which is slightly mobile region but the higher concentration of Ni found in residual fraction. The implication of this result is that Nickel and Zinc partially enter into the food chain. Chromium and Cadmium concentration result indicated that these metals can easily enter into the food chain because of their presence in the mobile region and their higher mobility percentage.
\end{abstract}

\section{Introduction}

The Itakpe iron ore mine came into existence as a result of the Federal Government of Nigeria desire for rapid industrialisation of the country through the iron and steel industry. The Itakpe iron ore deposit is the principal source for the iron and steel industry. As a result of the low grade of the Itakpe iron ore (36\%), beneficiation is required. The beneficiated iron ore from Itakpe is expected to feed the Ajaokuta Steel Complex, Ajaokuta Kogi State and Delta Steel Company Aladja Delta State, Nigeria. Specifically the mine was created in 1979 as Associated Ores Mining Company Limited (AOMC) and went through name changes before becoming National Iron Ore Mining Project Limited (NIOMP) in 1992. The corporate objectives of NIOMP are as follows: (i) to produce and supply $100 \%$ of the iron ore requirements of the Ajaokuta Steel Company Limited (ASCL) amounting to $2.15 \times 10^{6}$ tons per year assaying $63 \% \mathrm{Fe}$ (ii) to produce and supply $40 \%$ of the iron ore requirements of the Delta Steel Company, Aladja (Warri) (DSC), Nigeria amounting to 550,000 tons per year assaying 67 to $68 \%$ Fe as per initial design of Itakpe plant (iii) to export the concentrates to the international market after local needs have been satisfied (iv) to represent the interest of the Federal Government of Nigeria in foreign iron ore mining projects (v) to arrange and coordinate the exploitation of other locally available raw materials required by the major steel plants [1].

In the process of exploitation of the iron ore, wastes rocks are generated. Waste rocks at the Itakpe iron ore mine are associated rock mined during the exploitation of the deposit, while the tailings are waste generated during iron ore beneficiation [2]. Tailings are the products remaining after the extraction of metals by physical and chemical methods. At the Itakpe iron ore mine, the tailings are the bye-product of iron ore beneficiation. Tailings are mixtures of crushed rock and processing 
fluids from mills, washeries or concentrators that remain after the extraction of economic metals, minerals, mineral fuels or coal from the mine resource [3]. About 400,000 tons of tailings had been produced since the beneficiation of the ore started in 1993 at the Itakpe iron ore mine [4], while it can be estimated that about 632 million tonnes of iron ore tailings are generated yearly in Western Australia [5]. The tailings produced from the beneficiation of the ore were dumped in a waste pile lying there unutilised until recently when the petroleum industry in Nigeria started using it to coat pipelines to prevent corrosion.

At the Itakpe iron ore mine, the ratio of waste to ore is $4: 1$. The ratio of tailings to concentrate is commonly very high, generally around 200:1 [6]. For instance, it has been reported that in Western Australia, on average, the production of 1 tonne of iron ore results in the generation of 2 tonnes of iron ore tailings [7]. In Brazil, it is estimated that for each tonne of beneficiated iron ore, $400 \mathrm{~kg}$ of tailings are produced, and based on the 2014 production, about 275.5 million tonnes of waste was disposed of in landfills and tailing dams in 2014 [8]. Also, the output of iron tailings was around 500 million tons in 2015 [9]. Itakpe tailings are stockpiled in an open space of land dump, which may post environmental pollution issue if erosion occur and the possibility of the disposed tailings causing acid mine drainage and leaching of heavy metals to harm people and environment.

The total heavy metals in tailings samples is an effective method to identify environmental contamination but it is not enough to evaluate the impact of each element in probable pollution of the ecosystem [10]. However, speciation of metals in tailings and solid wastes is often studied to determine the impact of each metal on the environment whereby the target metals are fractionated into several fractions using extractant solutions of increasing strength $[11 ; 12 ; 13 ; 14]$.

Mineralogical techniques such as electron microscopy and X-ray diffraction (XRD), among others instrumental methods, are repeatedly engaged to elaborate on the data acquired by chemical speciation [15]. The iron ore tailings of Itakpe have been produced over three decades, its characteristics as it relates to pollution attributes has not been linked together; the study therefore examined these linkages to determine the leaching potential of the tailings. Therefore, it is very important to evaluate metals mobility/bioavailability base on the combine use of physical, chemical speciation mineralogical methods to actually ascertain the distribution of the metals which is the focus of the research.

\section{Tailings Characterisation}

The characteristic of the tailings depends on the type of ore mined. Tailings vary considerably in their chemical and physical characteristics and these characteristics include: mineralogical and geochemical compositions; specific gravity of tailings particles; settling behaviour; permeability vs. density relationships; soil plasticity (i.e. Atterberg limits); consolidation behaviour; rheology/viscosity characteristics; strength characteristics; pore water chemistry; and leaching properties $[16 ; 6]$. Further disaggregation of characterisation of tailings indicates both the physical, mechanical and chemical properties.

Common physical properties of tailings are; grain size, density, bulk density, specific gravity, porosity while some of the mechanical properties are shear strength and permeability. Some chemical properties of mine tailings include $\mathrm{pH}$, chemical composition etc.

The chemical composition of tailings depends on the mineralogy of the ore body, the nature of the processing fluids used to extract the economic metals, the efficiency of the extraction process and the degree of weathering during storage in the dammed impoundment [3]. The major components of Itakpe iron ore mine tailings are $71 \%$ of $\mathrm{SiO}_{2}$ and $2.62 \% \mathrm{Al}_{2} \mathrm{O}_{3}$ as shown in Table 1. The Fe (total) of $15 \%$ indicates that a sizeable amount of iron could still be further extracted as the beneficiation process improves. This shows that the ore recovery is not total. The tailings is 
brownish-dark, contains coarse and fine particles which made it useful for tailings dam as well for pipeline coatings.

A large percentage of the run-of-mine of the iron ore end up as waste rock and the tailings are generated from the beneficiation process.

Table 1. Chemical Composition of Itakpe Iron Ore Mine Tailings

\begin{tabular}{clc}
\hline $\mathrm{S} / \mathrm{n}$ & Component & Value (\%) \\
\hline i & $\mathrm{SiO}_{2}$ & 71 \\
ii & $\mathrm{Al}_{2} \mathrm{O}_{3}$ & 2.62 \\
iii & $\mathrm{Fe}($ total $)$ & 15 \\
iv & $\mathrm{TiO}_{2}$ & 0.2 \\
v & $\mathrm{CaO}$ & 1.2 \\
vi & $\mathrm{MgO}$ & 0.3 \\
vii & $\mathrm{P}$ & 0.08 \\
viii & $\mathrm{S}$ & 0.06 \\
ix & Total Alkali $\left(\mathrm{Na}_{2} \mathrm{O}+\mathrm{K}_{2} 0\right)$ & 1.2 \\
\hline
\end{tabular}

NIOMP [17]

\section{Location and Geology of the Study Area}

The National Iron Ore Mining Project (NIOMP) is located at Itakpe in Okehi Local Government Area of Kogi State, Nigeria. The iron ore deposit is on the eastern part of Kogi State, ten kilometers north of Okene township. The company (NIOMP) is located within latitude $8^{\circ}$ and $9^{\circ}$ and longitude $7^{\circ}$ and $8^{\circ}$. The Itakpe ridge consists of mainly Precambrian rocks, which are represented by; (i) migmatite gneiss complex (ii) meta - sedimentary rock series and (iii) older granite series [18].

Main classification adopted for the Itakpe iron ore deposit is based on [19]:

(a) Mineralogical classification

(i) Magnetite ore -------- Black streak

(ii) Heamatite ore -------- Reddish brown

(iii) Magnetite - Heamatite ore ----------- 50\% magnetite

(iv) Heamatite - Magnetite ore ----------- 50\% magnetite

(b) Commercial Classification

(i) Rich ores ------ $(45 \% \mathrm{Fe}$ in about $5 \%$ of mine $)$

(ii) Medium ores ------ $(31-45 \% \mathrm{Fe}$ in about $82 \%$ of mine $)$

(iii) Lean ores or poor grade ores ------ $(20-30 \%$ in about $13 \%$ of mine $)$

(c) Grain size classification

(i) Coarse grain

(ii) Medium grain

(iii) Fine grain 


\section{Methodology}

\section{Sample collection and preparation}

Samples were collected from the tailings dump within Itakpe iron ore mine. The samples were taken to the, The Federal Polytechnic Ado-Ekiti for physical property analysis (specific gravity, permeability, density, sieve analysis) and leaching property analysis. The sieving method was used for the determination of grain size distribution. The permeability of the tailings was measured using falling head permeability test and was carried out in a Falling Head permeability cell. The bulk density, specific gravity and porosity were measured using appropriate methods [20].

\section{Geochemical Speciation Procedure}

The geochemical speciation of metals was done by using modified Tessier as proposed by Ma and Uren [21] which partitions metals into exchangeable, bound to carbonates, bound to $\mathrm{Fe}-\mathrm{Mn}$ Oxides, bound to organic matter and residual. $1 \mathrm{~g}$ of air dried tailing sample was used. The results obtained were then validated by recovery experiment and the mobility factors were calculated [22].

Recovery is defined as shown in Equation 1:

$$
R=\frac{F 1+F 2+\cdots F n}{S D S A} X 100
$$

Where F1, F2 is Sequential Extraction Procedure and SDSA is Single Digestion with Strong Acids used for reference was a mixture of strong acids used in the residual fraction digestion [22].

The "Mobility Factor (MF)" is defined as a relative index of the mobility, which is calculated using Equation 2, [23]:

$$
\% \mathrm{MF}=\frac{\mathrm{F} 1+\mathrm{F} 2+\mathrm{F} 3}{\mathrm{~F} 1+\mathrm{F} 2+\mathrm{F} 3+\mathrm{F} 4+\mathrm{F} 5} \quad \mathrm{X} \quad 100
$$

Bioavailability factor $=$ Mobility factor $\mathrm{x} 100$.

For X-ray diffraction (XRD), $3 \mathrm{~g}$ samples were wet ground for $12 \mathrm{~min}$ in a micronizing mill to reduce the particle size to technically less than $10 \mu \mathrm{m}$ and the subsequent slurry sprayed dried directly from the mill [24]. The resulting powders were loaded into PANalytical Aeris diffractometer with PIXcel detector and fixed slits with $\mathrm{Fe}$ filtered $\mathrm{Co}-\mathrm{K} \alpha$ radiation. The phases were identified using X'Pert highscore plus software. The relative amounts (weight) were estimated using Rietveld method.

\section{Results and Discussion}

\section{Some Physical Properties of the Tailings}

Figure 1 show the particle-size distribution of the iron ore tailings. The result obtained from the sieve analysis of Itakpe iron ore tailings are of fine medium sand, this gives it more strength and reduced the porosity and permeability of the tailings. The chemical analysis indicates that the higher the silica (quartz) and haematite content in the tailings the finer the particles. The mean particle size $\mathrm{D}_{50}$ is 0.2 . 


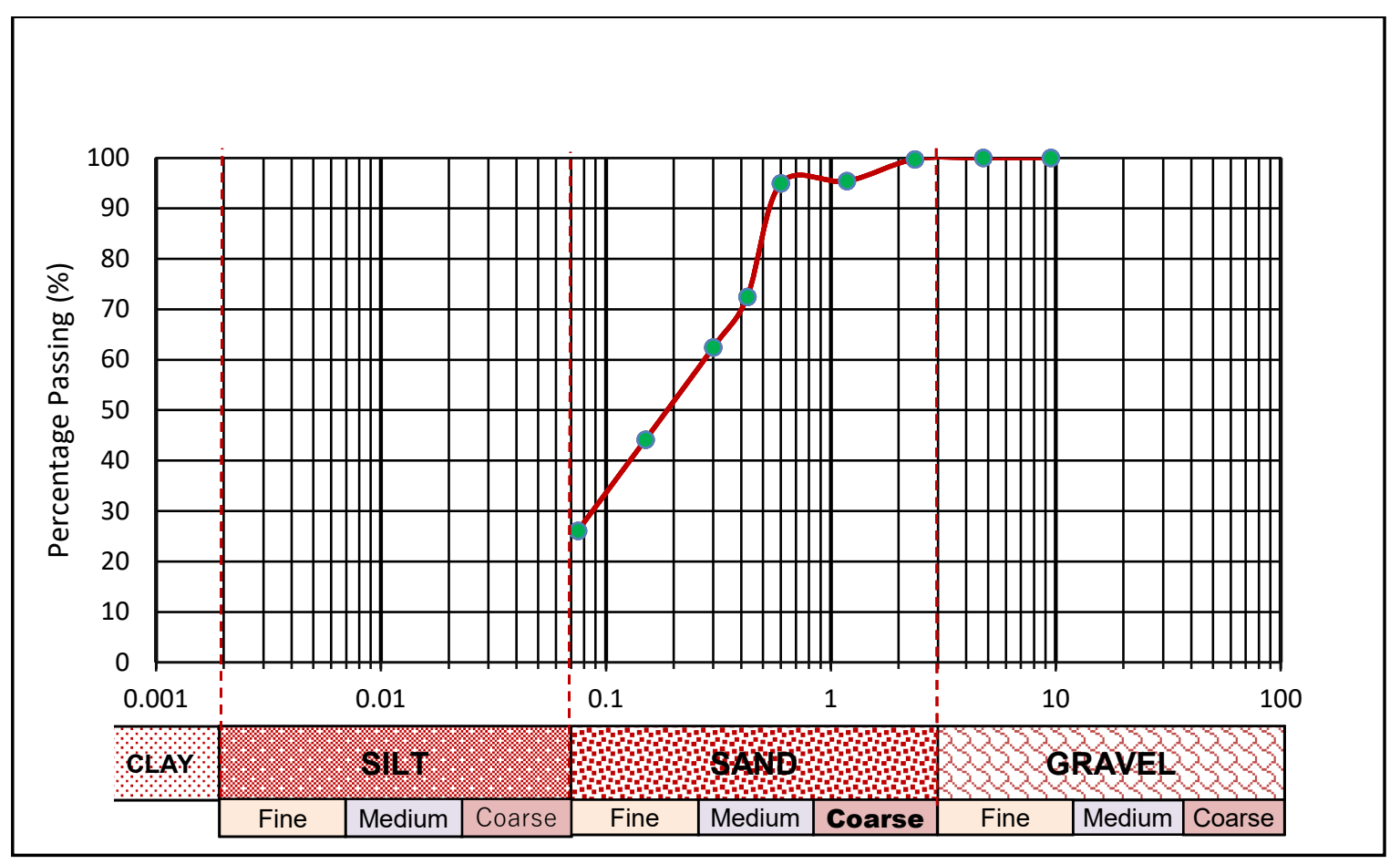

Figure 1. Particle-size Distribution of the Tailings

Particle size distribution is a property that controls the permeability of tailings. Permeability is of importance in determining the flow characteristics of ground water in a rock or grains. Permeability of the tailings largely depends on the finer particle sizes it contains. Permeability of the Itakpe iron ore tailings is $6.24 \times 10^{-3} \mathrm{~cm} / \mathrm{sec}$ as shown in Table 3 .

The mechanical properties of iron ore tailing improve as amount of porosity is reduced. The average porosity of Itapke iron ore tailings is $35 \%$ as presented in Table 3. The amount of silica present in the tailings affects the grain size which also affects the porosity because the finer the grain sizes of the tailings the closer the porous spaces.

The specific gravity of the tailing is 3.58 , which is higher than most natural soils. This indicates that the iron tailings are characterized as high compressible. The specific gravity obtained is consistent with values from tailings of most metal mines.

Table 3. Some Physical Properties Itakpe Iron Ore Tailings

\begin{tabular}{cll}
\hline S/n & \multicolumn{1}{c}{ Parameter } & \multicolumn{1}{c}{ Value } \\
\hline i. & Permeability & $6.24 \times 10^{-3} \mathrm{~cm} / \mathrm{sec}$ \\
ii & Porosity & $35 \%$ \\
iii. & Specific Gravity & 3.58 \\
\hline
\end{tabular}

\section{Geochemical Speciation}

The geochemical fractionation procedures results provided information on the potential mobility and bioavailability of the studied elements in this research. The distribution of heavy metals in the sample can be used to predict their mobility and bioavailability factor was expressed as the ratio of the available concentration of a metal in tailing to its total concentration. It predicts the potential or a particular metal for the soil matrix to enter the tailing solution from which it can enter food chain via plants Mobility factor was expressed as the percentage of bioavailability faction shown in Table 4. Nickel and Zinc was found to be considerably high in $F_{1}, F_{2}$ which are mobile region and in $F_{3}$ 
which is slightly mobile region but the higher concentration of Ni found in residual fraction (F5). This implication of this result is that Nickel and Zinc partially enter into the food chain.

Chromium and Cadmium concentration result indicated that these metals can easily enter into the food chain because of their presence in the mobile region and their higher mobility percentage. Fe is easily extractable for all the fractions with a considerably high concentration. Since the study are covered by Iron tailings

\section{Recoveries and Mobilities and Bioavailability Factor of Element}

The metal concentrations, percentage recovery, mobility and bioavailability factors to all sequential extraction steps including the residual phase fractions, determined at each extraction step in Table 6, indicated that metal has a characteristic distribution pattern.

Table 6 show the mobility and bioavailability factors and percentage recovery of $\mathrm{Ni}$ for all the sequential extractions steps. The MF of $\mathrm{Ni}$ gave average value of $19.1 \%$ while average $\mathrm{BF}$ of $\mathrm{Ni}$ was 0.19.the percentage recovery of Ni ranged from 94.69-93.28\%.the high MF and BF value of tailing Ni may be interpreted as symptoms of relatively high liability and biological availability of the metals in tailings $[25 ; 26]$. Similar characteristics distribution patterns were observed for $\mathrm{Cd}, \mathrm{Cr}$ and Fe except $\mathrm{Zn}$ with low $\mathrm{Mf}$ of $13.8 \%$ and $\mathrm{Bf}$ of 0.14 as shown in Table 4 . The average mobility of $\mathrm{Ni}, \mathrm{Cd}, \mathrm{Cr}, \mathrm{Fe}$ and $\mathrm{Zn}$ levels of all five fractions were in the order: $\mathrm{Cd}>\mathrm{Cr}>\mathrm{Fe}>\mathrm{Ni}>\mathrm{Zn}$.

Table 4. Geochemical Fraction of Itakpe Iron Tailings

\begin{tabular}{cccccccccccc}
\hline Element Sample & F1 & F2 & F3 & F4 & F5 & Total & $\begin{array}{c}\text { Original } \\
\text { Sample }\end{array}$ & $\begin{array}{c}\text { Recovery } \\
\text { Rf }\end{array}$ & \%Mf \\
\hline $\mathrm{Ni}$ & 1 & 6.20 & 6.45 & 5.00 & 1.00 & 47.55 & 66.20 & 69.91 & 94.69 & 0.19 & 19.10 \\
& 2 & 8.50 & 7.50 & 5.00 & 0.00 & 46.01 & 67.01 & 71.84 & 93.28 & 0.24 & 23.80 \\
\hline $\mathrm{Zn}$ & 1 & 3.50 & 12.50 & 11.10 & 7.00 & 33.00 & 67.10 & 58.19 & 115.31 & 0.24 & 23.80 \\
& 2 & 2.40 & 6.00 & 9.46 & 7.00 & 36.00 & 60.86 & 59.81 & 101.76 & 0.14 & 13.80 \\
\hline $\mathrm{Cr}$ & 1 & 0.01 & 2.22 & 0.00 & 2.41 & 0.40 & 5.04 & 6.58 & 76.59 & 0.44 & 44.20 \\
& 2 & 0.01 & 4.78 & 0.00 & 4.22 & 0.81 & 9.82 & 12.00 & 81.83 & 0.39 & 39.90 \\
\hline $\mathrm{Cd}$ & 1 & 0.05 & 0.20 & 0.34 & 0.15 & 0.15 & 0.89 & 1.67 & 53.29 & 0.28 & 28.10 \\
& 2 & 1.10 & 0.30 & 0.30 & 0.05 & 0.05 & 1.80 & 2.10 & 85.71 & 0.67 & 66.70 \\
\hline $\mathrm{Fe}$ & 1 & 23.40 & 490.15 & 460.10 & 545.90 & 318.20 & 1837.75 & 2560.20 & 71.78 & 0.27 & 27.90 \\
& 2 & 25.50 & 360.90 & 450.50 & 380.80 & 450.00 & 1667.70 & 2765.90 & 60.29 & 0.23 & 23.20 \\
\hline
\end{tabular}

\section{Mineralogy Analysis}

In total 30 crystalline phases were identified and quantified from tailings composite samples as shown in Figure 2 shows the mineral composition of Iron Ore Tailings (IOT). X-ray diffraction (XRD) analysis indicates that the main crystalline phases were quartz $\left(\mathrm{SiO}_{2}\right)$, Hornblende, Amphibole, Haematite, Magnetite, Calcite and Plagioclase. 
The tailing profile is rich in Quartz (0.92-12.28\%), Plagioclase (3.24-6.01\%), Chlorite (4.405.64\%), Amphibole (1.14-2.59\%) and Kaolinite 2.24\%. Iron oxides are present in substantial concentration in the tailings (Haematite 3.68-7.38\%, Magnetite 2.09-5.52\%).

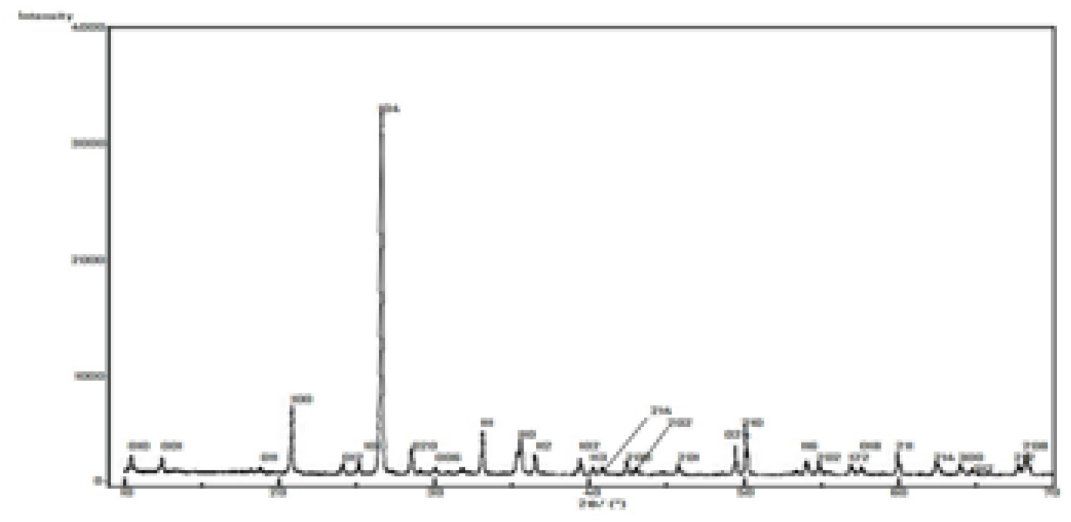

Figure 2. XRD Pattern of Itakpe Iron Ore Tailings

\section{Conclusions and Recommendations}

The Itakpe iron ore mine tailings is fine medium sand with low porosity, permeability and high specific gravity. The main crystalline phases of the tailings were quartz $\left(\mathrm{SiO}_{2}\right)$, Hornblende, Amphibole, Haematite, Magnetite, Calcite and Plagioclase. Geochemical fractionation results indicated that Nickel and Zinc partially enter into the food chain.

Chromium and Cadmium concentration result indicated that these metals can easily enter into the food chain because of their presence in the mobile region and their higher mobility percentage. The average mobility of $\mathrm{Ni}, \mathrm{Cd}, \mathrm{Cr}, \mathrm{Fe}$ and $\mathrm{Zn}$ levels of all five fractions were in the order: $\mathrm{Cd}>\mathrm{Cr}>\mathrm{Fe}$ $>\mathrm{Ni}>\mathrm{Zn}$. There is need for improvement in the beneficiation process of the iron ore which will lead to increase recovery of the hematite-magnetite ore. Also, the oil industry in Nigeria should be encouraged to continue to make use of the tailings for pipeline protection.

\section{Conflict of Interest}

The authors declare that there is no conflict of interest in this manuscript.

\section{References}

[1] U. Turaki. Management of the mineral sector in a depressed economy: NIOMP experience. Nigerian Mining Journal, 2(1) (1997): 12 - 19.

[2] R. A. Adebimpe. Evaluation and stability analysis of solid mine wastes of Itakpe iron ore mine. M.Eng Thesis (Unpublished). The Federal University of Technology, Akure, Ondo State. Nigeria. (2004) p.2

[3] D. Kossoff, W.E. Dubbin, M. Alfredsson, S.J. Edwards, M.G. Macklin, K.A.HudsonEdwards. Mine tailings dams: Characteristics, failure, environmental impacts, and remediation. Applied Geochemistry 51 (2014) 229-245.

[4] R. A. Adebimpe, and J.A. Adam. Investigation of the suitability of National Iron Ore Mining tailings for brick production. Proceedings of the $22^{\text {nd }}$ World Mining Congress, $11^{\text {th }}-16^{\text {th }}$ September, 2011, Istanbul, Turkey. (2) (2011): 581-592.

[5] F.A, Kuranchie, S.K, Shukla, D. Habibi and A. Mohyeddin. Utilisation of iron ore tailings as aggregates in concrete. Congent Engineering. 2015-Issue 1

[6] B. Lottermoser. Mine wastes: characterization, treatment and environmental impacts. Springer, Berlin, Heidelberg, New York. (2007) 
[7] P.A. Price. Description of operating procedures of BHP Billiton iron ore (Document number 12622268, (2004) 1-31).

[8] P.D Dauce, B.G de Castro, M.M.F Lima, and R.M.F. Lima. Characterisation and magnetic concentration of an iron ore tailings. Journal of Materials Research and Technology. 8(1) (2019): 1052-1059

[9] Jiang, J.H, Ye, G.H, S.M. Hu. The technology status and research progress of iron tailings rebeneficiation.Min. Metall. 27 (2018) 1-4.

[10] A.M. Ure, C.M, Davidson,. Chemical speciation in soils and related materials by selective chemical cpeciation. In: Uren, A.M., Davidson, C.M (Eds), Chemical speciation in the environment. Blackwell Science, Oxford, (2002): 265-300

[11] A. Tessire, P.G.C. Campbell, M. Blsson. Sequential extraction procedure for the speciation of soils. Speciation Chemistry 51(7) (1979): $844-855$.

[12] R. Chester, M.J. Hughes. A chemical technique for the speciation of ferro manganese minerals, carbonate minerals and adsorbed trace elements from pelagic sediments. Chem. Geol., 2(1967): 249-263.

[13] R.M. Brown, C.T. Pickford, W.L. Davison. Speciation of metals in soils. International Journal of Environmental Analytical Chemistry, 18 (1984): 135-141.

[14] M.J. Gibson and J.G Farmer. Multi-step sequential chemical extraction of heavy metals from urban soils. Environ. Pollut. Ser. B, 11(2) (1986).: 117-135.

[15] P.C.Ryan, A.J. Wall, S. Hillier, L.Clark. Insights into sequential chemical extraction procedures from quantitative XRD: A study of trace metal partitioning in sediments related to frog malfomitics, Chemical Geology, 184(2002) 337-357

[16] Environment Australia. Tailings containment. Best practice environmental management in mining. Environment Australia, Canberra, (1995).

[17] NIOMP . NIOMP Handbook. ITAKPE, (2001).

[18] M.A. Olade. Precambian iron ore deposits and its environment at Itakpe ridge, Okene, Nigeria. Institute of Mining and Metallurgy London. February, (1978) B1 - B9.

[19] NIOMP. Itakpe project report. Parts I and II (Unpublished Report). (1979).

[20] British Standard 1377 (BS 1377). British Standard Methods of Test for Soils for Civil Engineering Purposes, UK: London, British Standards Institution. 1990.

[21] Y.B. Ma, and N.C. Uren. Transformation of Heavy Metals added to Soil- Application of a new Sequential Extraction Procedure. Geoderma,84, (1998) 157-168.

[22] K. Boch, M. Schuster, G. Risse, M. Schwarzer. Analytical Chemistry Acta. (2002) 257

$-459$.

[23] C. Kabala, B.R Singh. Fractionation and mobility of copper, lead and zinc in soil profiles in the vicinity of a copper smelter. Journal Environmental Quality. 30, (2001) 485-492.

[24] P. Lavazzo, P. Adamo, M. Boni, S. Hillier, M. Zampella. Mineralogy and Chemical form of Lead and Zinc in Abanboned Mine Wastes and Soils: An example from Morocco, Journal of Geochemical Exploration, 113 (2011) 56-67.

[25] L.Q. Ma, and G.N. Rao. Chemical Fractionation of Calcium, Copper, Nickel and Zinc in contaminated soils. J. Env. Qual. 26 (1997) 259 - 264.

[26] J. Gzyl. Lead and cadmium contamination of soil and vegetables in the Upper Silasia Region of Poland. Sci. Total Env. (1996) $119-209$. 